\title{
Front Matter: Volume 10094
}

, "Front Matter: Volume 10094," Proc. SPIE 10094, Frontiers in Ultrafast Optics: Biomedical, Scientific, and Industrial Applications XVII, 1009401 (15 March 2017); doi: 10.1117/12.2276126

SPIE. Event: SPIE LASE, 2017, San Francisco, California, United States 


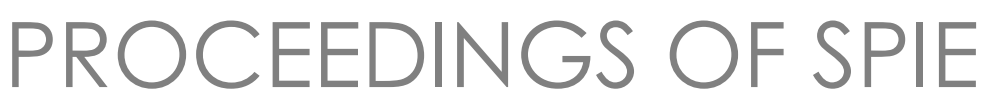

\title{
Frontiers in Ultrafast Optics: Biomedical, Scientific, and Industrial Applications XVII
}

\author{
Alexander Heisterkamp \\ Peter R. Herman \\ Michel Meunier \\ Roberto Osellame \\ Editors \\ 29 January - 2 February 2017 \\ Sponsored by \\ SPIE \\ Cosponsored by \\ Amplitude Systèmes (France) \\ APE GmbH (Germany) \\ TRUMPF Inc. (United States) \\ Published by \\ SPIE
}

San Francisco, California, United States 
The papers in this volume were part of the technical conference cited on the cover and title page. Papers were selected and subject to review by the editors and conference program committee. Some conference presentations may not be available for publication. Additional papers and presentation recordings may be available online in the SPIE Digital Library at SPIEDigitallibrary.org.

The papers reflect the work and thoughts of the authors and are published herein as submitted. The publisher is not responsible for the validity of the information or for any outcomes resulting from reliance thereon.

Please use the following format to cite material from these proceedings:

Author(s), "Title of Paper," in Frontiers in Ultrafast Optics: Biomedical, Scientific, and Industrial Applications XVII, edited by Alexander Heisterkamp, Peter R. Herman, Michel Meunier, Roberto Osellame, Proceedings of SPIE Vol. 10094 (SPIE, Bellingham, WA, 2017) Seven-digit Article CID Number.

ISSN: 0277-786X

ISSN: 1996-756X (electronic)

ISBN: 9781510606296

ISBN: 9781510606302 (electronic)

Published by

SPIE

P.O. Box 10, Bellingham, Washington 98227-0010 USA

Telephone +1 3606763290 (Pacific Time) · Fax +1 3606471445

SPIE.org

Copyright (@) 2017, Society of Photo-Optical Instrumentation Engineers.

Copying of material in this book for internal or personal use, or for the internal or personal use of specific clients, beyond the fair use provisions granted by the U.S. Copyright Law is authorized by SPIE subject to payment of copying fees. The Transactional Reporting Service base fee for this volume is $\$ 18.00$ per article (or portion thereof), which should be paid directly to the Copyright Clearance Center (CCC), 222 Rosewood Drive, Danvers, MA 01923. Payment may also be made electronically through CCC Online at copyright.com. Other copying for republication, resale, advertising or promotion, or any form of systematic or multiple reproduction of any material in this book is prohibited except with permission in writing from the publisher. The CCC fee code is 0277-786X/17/ \$18.00.

Printed in the United States of America.

Publication of record for individual papers is online in the SPIE Digital Library.

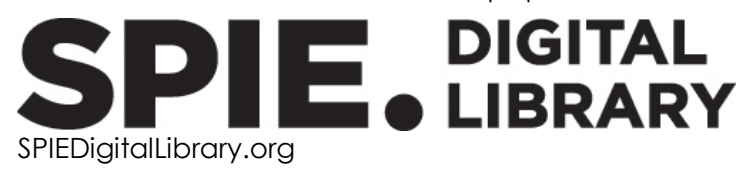

Paper Numbering: Proceedings of SPIE follow an e-First publication model. A unique citation identifier (CID) number is assigned to each article at the time of publication. Utilization of CIDs allows articles to be fully citable as soon as they are published online, and connects the same identifier to all online and print versions of the publication. SPIE uses a seven-digit CID article numbering system structured as follows:

- The first five digits correspond to the SPIE volume number.

- The last two digits indicate publication order within the volume using a Base 36 numbering system employing both numerals and letters. These two-number sets start with 00, 01, 02, 03, 04, 05, $06,07,08,09,0 A, O B \ldots$. OZ, followed by 10-1Z, 20-2Z, etc. The CID Number appears on each page of the manuscript. 


\title{
Contents
}

\author{
vii Authors \\ ix Conference Committee
}

\section{NOVEL BIOMEDICAL APPLICATIONS}

1009403 Fabrication of 3D micro-structured scaffolds by direct laser writing in pre-polymers for in vitro and in vivo studies [10094-2]

1009405 Precision resection of lung cancer in a sheep model using ultrashort laser pulses [10094-5]

1009406 Multiphoton signal increase due to repetition rate doubling in a photonic crystal rod [10094-6]

\section{NANOSURGERY AND TRANSFECTION I}

10094 OA Single cell manipulation utilizing femtosecond laser-induced shock and stress waves (Invited Paper) [10094-10]

\section{NOVEL BEAM DELIVERY AND CONTROL}

10094 ON Development of a dynamic interferometric focusing system for femtosecond laser machining [10094-23]

1009400 Analysis of ultrafast material processing using flexible beam delivery [10094-24]

\section{NOVEL CONCEPTS IN ULTRAFAST LASER PROCESSING}

$100940 Q$ Plasmonic coloring of noble metals rendered by picosecond laser exposure [10094-26]

10094 OR Picosecond laser ablation of polyamide electrospun nanofibers [10094-27]

\section{D STRUCTURING OF TRANSPARENT MATERIALS I}

$10094 \mathrm{OV}$ Towards optical quality micro-optic fabrication by direct laser writing and chemical etching [10094-31] 
$1009411 \quad$ Ultrashort pulse laser welding of glasses without optical contacting [10094-37]

SCRIBING TRANSPARENT MATERIALS: JOINT SESSION WITH CONFERENCES 10091 AND 10094

1009417 Latest advances in machining of transparent, brittle materials using non-ablative femtosecond laser processing from Spectra-Physics [10094-43]

ULTRAFAST LASERS FOR CHARACTERIZATION: JOINT SESSION WITH CONFERENCES 10091 AND 10094

10094 1D Reproducing space weathering of olivine by using high-energy femtosecond laser pulses [10094-49]

10094 IE Two-beam femtosecond rotational CARS for one-dimensional thermometry in a turbulent, sooting jet flame [10094-50]

10094 IF Femtosecond, fully resonant electronically enhanced CARS (FREE-CARS) for simultaneous single-shot thermometry and detection of minor combustion species [10094-51]

$100941 G \quad$ Time-resolved correlated measurement of laser-induced-breakdown spectroscopy and electron number density: application to high-pressure hydrocarbon flames [10094-52]

INDUSTRIAL APPLICATIONS: SYSTEMS: JOINT SESSION WITH CONFERENCES 10091 AND 10094

$10094 \mathrm{lH} \quad$ Ultra-short pulse delivery at high average power with low-loss hollow core fibers coupled to TRUMPF's TruMicro laser platforms for industrial applications [10094-53]

$1009411 \quad H i g h$ power mid-IR OPCPA system pumped by a femtosecond Yb-doped fiber amplifier [10094-54]

$100941 \mathrm{~L} \quad$ Kagome fiber based industrial laser beam delivery [10094-57]

$100941 \mathrm{M} \quad$ Ultra-low loss (8.5 dB/km @ Yb-laser wavelength range) inhibited-coupling Kagome HCPCF for laser beam delivery applications [10094-58]

POSTER SESSION

$10094 \mathrm{lN}$ Study on parameters of fiber loop mirrors as artificial saturable absorbers [10094-59]

1009410 Ultrafast pulsed Bessel beams for enhanced laser ablation of bone tissue for applications in LASSOS [10094-60]

$100941 Q \quad$ Improving the fidelity of two-photon absorption reference standards [10094-62] 
10094 IR Determination of the limits of detection of the elements in aqueous solutions by femtosecond LIBS depending on the laser pulse repetition rate [10094-63]

10094 IT Acceleration of biodegradation by ultraviolet femtosecond laser irradiation to biodegradable polymer [10094-65]

$100941 \mathrm{U}$ Enhancement of laser machining resolution using the two photon absorption effect [10094-66]

1009421 Monostatic and bistatic lidar systems: simulation to improve SNR and attainable range in daytime operations [10094-73] 
Proc. of SPIE Vol. 10094 1009401-6

Downloaded From: https://www.spiedigitallibrary.org/conference-proceedings-of-spie on 26 Apr 2023 Terms of Use: https://www.spiedigitallibrary.org/terms-of-use 


\section{Authors}

Numbers in the index correspond to the last two digits of the six-digit citation identifier (CID) article numbering system used in Proceedings of SPIE. The first five digits reflect the volume number. Base 36 numbering is employed for the last two digits and indicates the order of articles within the volume. Numbers start with 00, 01, 02, 03, 04, 05, 06, 07, 08, 09, OA, OB...0Z, followed by 10-1Z, 20-2Z, etc.

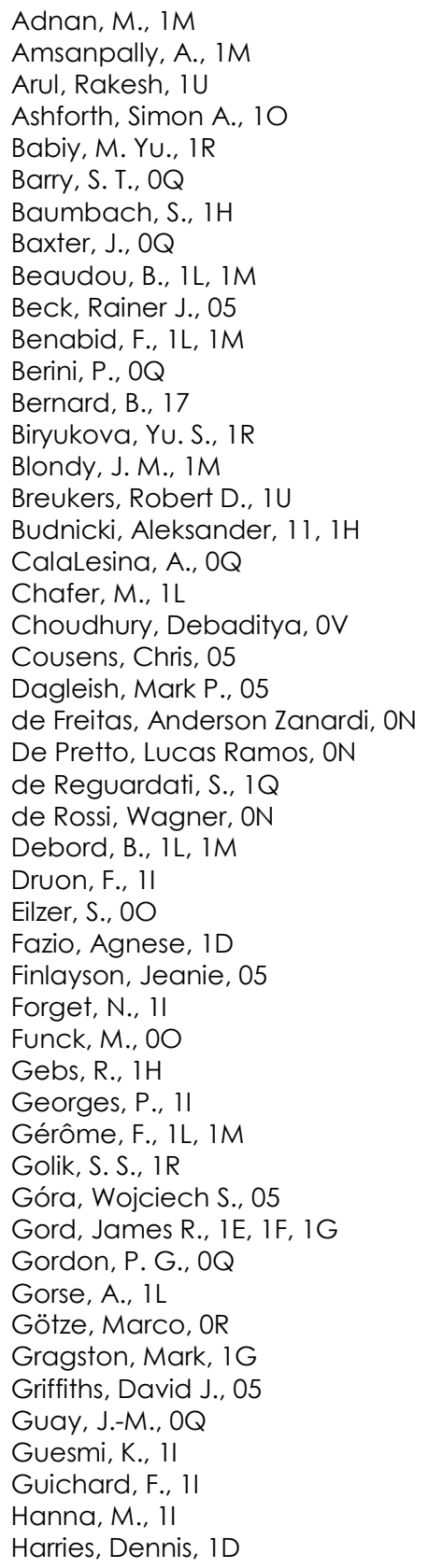

Hassebo, Ahmed, 21

Hassebo, Yasser Y., 21

$\mathrm{He}$, Jiexing, $\mathrm{O6}$

Heilmann, Andreas, OR

Hendricks, F., 17

Henning, Sven, OR

Hillrichs, Georg, OR

Hosokawa, Yoichiroh, OA

Hsu, Paul S., $1 G$

Ilyin, A. A., IR

Kahmann, M., 1H

Kardaś, Tomasz, $1 \mathrm{~N}$

Kearney, Sean P., $1 \mathrm{E}$

Killi, A., $1 \mathrm{H}$

Kleinbaver, J., $1 \mathrm{H}$

Kondo, Naonari, IT

Krimig, Olaf, OR

Kürbitz, Tobias, OR

Langenhorst, Falko, 1D

Lekiefs, Q., $1 \mathrm{~L}$

Mačiulaitis, Justinas, 03

Mačiulaitis, Romaldas, 03

MacLachlan, David G., OV

Malinauskas, Mangirdas, 03

Matthäus, Gabor, 1D

Matylitsky, V., 17

Maurel, M., 1L, 1M

Mayor, A. YU., IR

Mohanan, Syam Mohan P. C., 05

Mutschke, Harald, ID

Nejbaver, Michał, IN

Nolte, Stefan, 11, 1D

Nutsch, S., $1 \mathrm{H}$

Oosterbeek, Reece N., 10, $1 U$

Overbuschmann, J., $1 \mathrm{H}$

Pahapill, J., 1Q

Patnaik, Anil K., $1 G$

Pricking, S., $1 \mathrm{H}$

Proschenko, D. YU., IR

Qiu, Ping, 06

Radzewicz, Czesław, IN

Raele, Marcus Paulo, ON

Rammo, M., 1Q

Ramunno, L., OQ

Rebane, A., $1 Q$

Rekštytè, Sima, 03

Richardson, Daniel R., 1E, IF

Richter, Sören, 11

Rigaud, P., 11 
Ross, Calum, OV

Roy, Sukesh, IE, IF, IG

Salas, Balbina, 21

Samad, Ricardo Elgul, ON

Scelle, R., 1H

Schmidt, Jacob B., IF

Shephard, Jonathan D., 05

Shibata, Akimichi, IT

Simpson, M. Cather, 10, $1 \mathrm{U}$

Stauffer, Hans U., IF

Stepanenko, Yuriy, $1 \mathrm{~N}$

Stępień, Witold, $1 \mathrm{~N}$

Sutter, Dirk, H., 11, 1H

Szczepanek, Jan, iN

Tan, C., $1 \mathrm{H}$

Terakawa, Mitsuhiro, IT

Thomson, Robert R., OV

Tünnermann, Andreas, 11

Van de Walle, A., 11

Vieira Junior, Nilson Dias, ON

Vincetti, L., 1M

Wang, Ke, 06

Ward, Thomas, $1 \mathrm{U}$

Weck, A., OQ

Wedel, B., 00

Wetter, Niklaus Ursus, ON

Wrzesinski, Paul J., IF

Wu, Yue, $1 \mathrm{G}$

Yada, Shuhei, $1 \mathrm{~T}$

Zaouter, Y., 11

Zhang, Zhili, IG

Zimmermann, Felix, 11 


\section{Conference Committee}

Symposium Chairs

Reinhart Poprawe, Fraunhofer-Institut für Lasertechnik (Germany)

Koji Sugioka, RIKEN (Japan)

Symposium Co-Chairs

Guido Hennig, Daetwyler Graphics AG (Switzerland)

Yongfeng Lu, University of Nebraska-Lincoln (United States)

Program Track Chairs

Beat Neuenschwander, Berner Fachhochschule Technik und Informatik (Switzerland)

Henry Helvajin, The Aerospace Corporation (United States)

Conference Chairs

Alexander Heisterkamp, Leibniz Universität Hannover (Germany)

Peter R. Herman, University of Toronto (Canada)

Michel Meunier, Ecole Polytechnique de Montréal (Canada)

Roberto Osellame, CNR-Istituto di Fotonica e Nanotecnologie (Italy)

Conference Program Committee

Craig B. Arnold, Princeton University (United States)

Yves Bellouard, Ecole Polytechnique Fédérale de Lausanne

(Switzerland)

Adela Ben-Yakar, The University of Texas at Austin (United States)

Denise M. Krol, University of California, Davis (United States)

Eric Mazur, Harvard University (United States)

Eric P. Mottay, Amplitude Systèmes (France)

Beat Neuenschwander, Berner Fachhochschule Technik und Informatik (Switzerland)

Stefan Nolte, Friedrich-Schiller-Universität Jena (Germany)

Christopher B. Schaffer, Cornell University (United States)

Koji Sugioka, RIKEN (Japan)

Mitsuhiro Terakawa, Keio University (Japan)

Alfred Vogel, Universität zu Lübeck (Germany)

Sascha Weiler, TRUMPF Inc. (United States)

Dvir Yelin, Technion-Israel Institute of Technology (Israel) 


\section{Session Chairs}

1 Novel Biomedical Applications

Alexander Heisterkamp, Leibniz Universität Hannover (Germany)

2 Nanosurgery and Transfection I

Michel Meunier, Ecole Polytechnique de Montréal (Canada)

3 Nanosurgery and Transfection II

Norbert Linz, Universität zu Lübeck (Germany)

4 Nanosurgery and Transfection III

Mitsuhiro Terakawa, Keio University (Japan)

5 Novel Beam Delivery and Control

Patrick S. Salter, University of Oxford (United Kingdom)

6 Novel Concepts in Ultrafast Laser Processing

Yves Bellouard, Ecole Polytechnique Fédérale de Lausanne

(Switzerland)

7 3D Structuring of Transparent Materials I

Stefan Nolte, Friedrich-Schiller-Universität Jena (Germany)

8 3D Structuring of Transparent Materials II

Michael J. Withford, Macquarie University (Australia)

9 Nanostructured Optical Fibers: Joint Session with Conferences 10091 and 10094

Roberto Osellame, CNR-Istituto di Fotonica e Nanotecnologie (Italy)

10 Scribing Transparent Materials: Joint Session with Conferences 10091 and 10094

Peter R. Herman, University of Toronto (Canada)

11 Laser Interaction Dynamics: Joint Session with Conferences 10091 and 10094

Guido Hennig, Daetwyler Graphics AG (Switzerland)

12 Ultrafast Lasers for Characterization: Joint Session with Conferences 10091 and 10094

Jean-Philippe Colombier, Université Jean Monnet Saint-Etienne (France) 
13 Industrial Applications: Systems: Joint Session with Conferences 10091 and 10094

Eric P. Mottay, Amplitude Systèmes (France)

14 Industrial Applications: Processes: Joint Session with Conferences 10091 and 10094

Malte Kumkar, TRUMPF Laser- und Systemtechnik GmbH (Germany)

Proc. of SPIE Vol. 10094 1009401-11

Downloaded From: https://www.spiedigitallibrary.org/conference-proceedings-of-spie on 26 Apr 2023 Terms of Use: https://www.spiedigitallibrary.org/terms-of-use 
Proc. of SPIE Vol. 10094 1009401-12 Downloaded From: https://www.spiedigitallibrary.org/conference-proceedings-of-spie on 26 Apr 2023
Terms of Use: https://www.spiedigitallibrary.org/terms-of-use 